\title{
Life of Guido Guidi (Vidus Vidius), who named the Vidian canal
}

\author{
Illhan Bahşi ${ }^{1}$ (D) \\ Received: 16 July 2018 / Accepted: 23 July 2018 / Published online: 31 July 2018 \\ (C) Springer-Verlag GmbH Germany, part of Springer Nature 2018
}

\section{His life}

Guido Guidi (Latinized name Vidus Vidius) was an Italian anatomist and surgeon [1]. In the literature, much of the details regarding his life are lacking. He was born in Florence [2]. Different information is present about his date of birth in the literature: there are sources indicating that he was born in 1500 [3], 10 February 1508 [4], 1500/ 1509 [5], 1509 [2], and 10 February 1509 [1]. His mother (Costanza) was daughter of painter Domenico del Ghirlandajo who work as an apprentice for Michelangelo [2, 4]. His father, Giuliano di Guido dei Guidi was a family of physicians [4].

He probably trained in medicine and surgery in a native city and soon after that earned reputation as a good capable surgeon and anatomist [3]. Since he finished medical school, he worked as a doctor in Rome and Florence [2]. In 1542, he went to Paris and he served as a physician of Francis I, king of France [3]. He named royal physician in Paris and he became the first professor at College Royal [4]. During the six years in France, he had made a good friendship with Benvenuto Cellini who was an Italian goldsmith, sculptor, draftsman, soldier, musician, and artist who also wrote a famous autobiography and poetry [3].

In 1547, after the death of Francis I, Guidi had to leave from Paris and returned to his hometown [4]. Here, he was appointed to Cosmo de Medici as a chief physician [3]. In 1548, he served to Department of Philosophy and Medicine in University of Pisa that he was appointed as a professor for twenty years [4]. Guidi died on 26 May 1569 in Pisa [3]. According to Thompson [3], Guido was one of the instructors of Andreas Vesalius.

İlhan Bahși

dr.ilhanbahsi@gmail.com

1 Department of Anatomy, Faculty of Medicine, Gaziantep University, TR 27310 Gaziantep, Turkey

\section{His works}

Thompson [3] said that Benvenuto Cellini has told us in his autobiography that near the house in which he had lived in Paris, there were some little dwellings inhabited by different sorts of men, among whom was a printer of books of much excellence in his own trade. He was Petrus Galterius who was first printed the named Chirurgia è graeco in latinum conuersa, Vido Vidio Florentino interprete cum nonnullis ejusdem Vidii cõmentarijs of Guido Guidi in 1544. This book is paper that complied to the works of ancient Greek surgeons and prepared as handwritten by Nicetas in the 10th century. Guidi had translated this book Greek into Latin and he added to his interpretations. Guidi indicated that the translation of this book for Francis I [3]. This book consists of 580 pages. The book contains information about the works of Hippocrates, Galen, and Oribasius. Also, it includes many tools and machines used by these people (Fig. 1).

After 1548, Guidi studied important anatomical research in Pisa. According to Gillispie [4], Guidi certainly described the vertebrae, cartilaginous structures, and the bones of the cranium better than any of his predecessors. Besides, his name use as eponym to pterygoid canal located on sphenoid bone (Vidian canal) and as eponym to nerve of pterygoid canal on this canal (Vidian nerve). Also, he made original works of the mechanism of articulation in the human body resulting from its vertical position in relation to the mechanism of quadruped articulations [5]. It is also known that Guidi was one of the first to identify the varicella infection, developed by various devices from Hippocrates to reduce fractures detection and dislocations, and invented a unique method for tracheotomy [2].

The anatomical study of Guidi was published in the year 1596 or 1611 with pictures made by his nephew, after his death, under the name of Florentini de anatome corporis humani libri VII. This book consists of 358 pages. There are many illustrations in this book. 

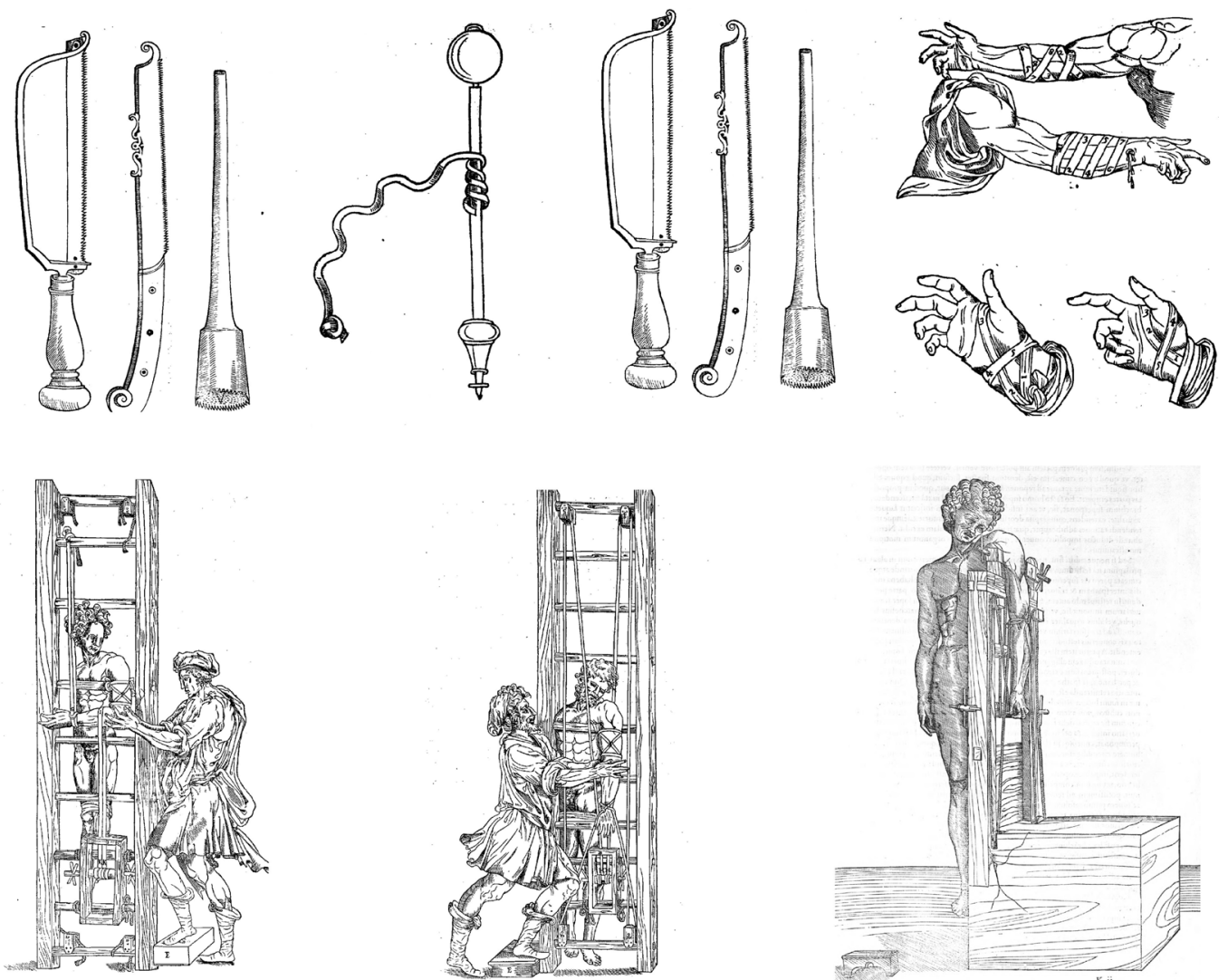

Fig. 1 Some illustrations in Chirurgia è graeco in latinum conuersa, Vido Vidio Florentino interprete cum nonnullis ejusdem Vidii cõmentarijs
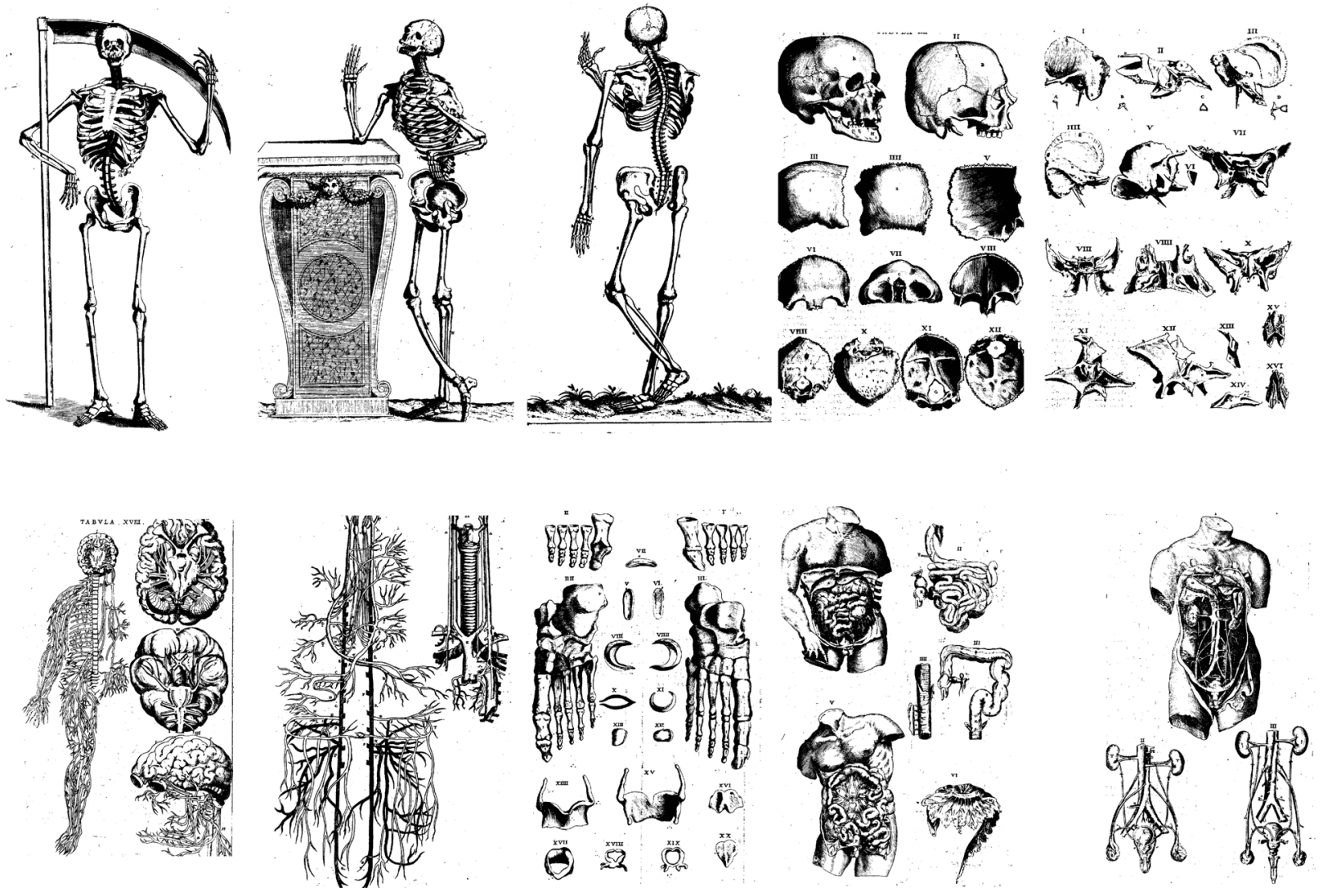

Fig. 2 and cover Some illustrations in Florentini de anatome corporis humani libri VII 
Fig. 3 Some illustrations that had drawn clumsily in Florentini de anatome corporis humani libri VII
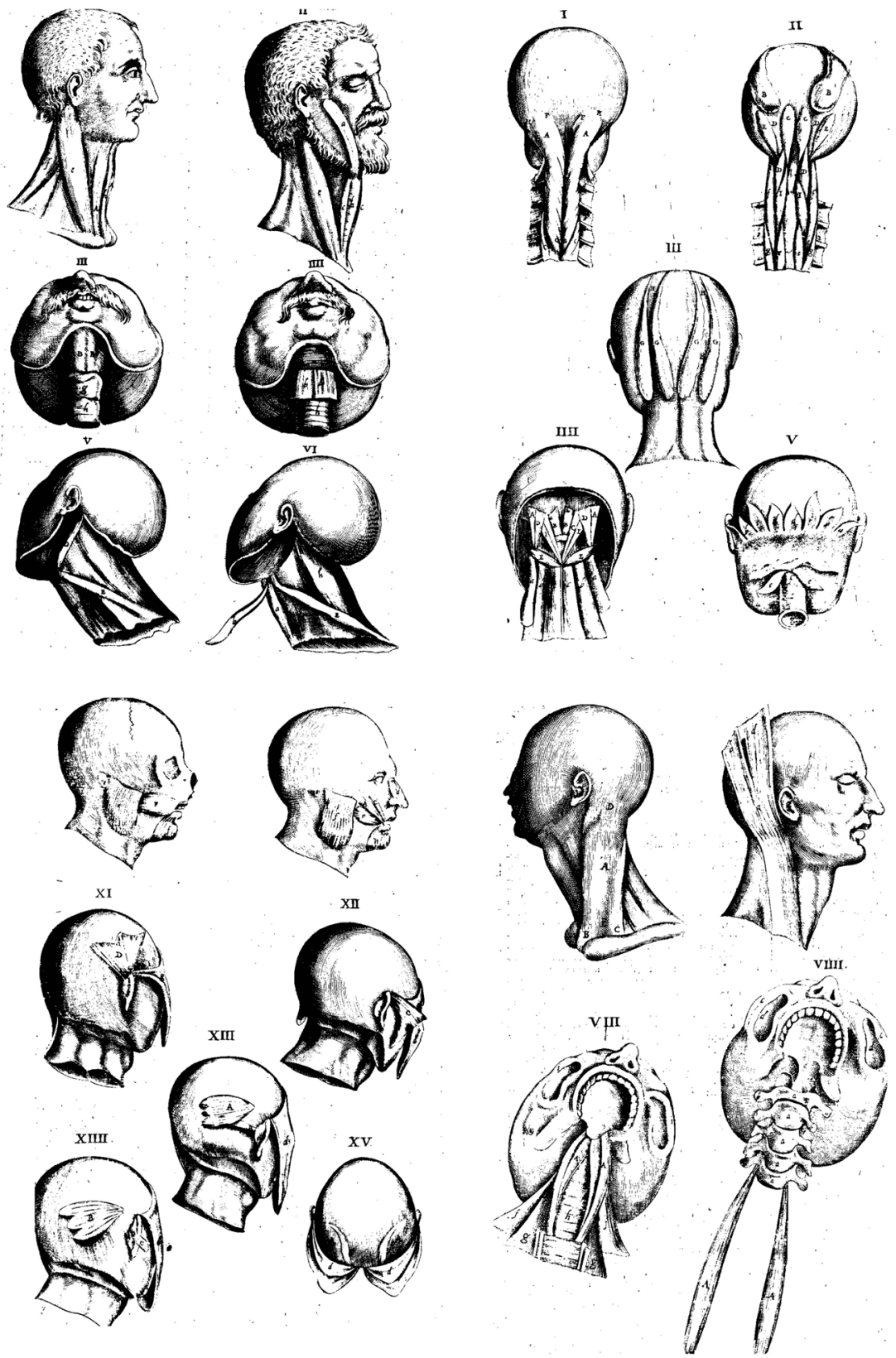

Some of these illustrations were classical anatomic drawing. Others were drawings of anatomical drawings with an artistic point of view. In the first part of the book, the bones are described in detail and supported by many pictures. Then, the nervous system, vessels, muscles, internal organs, stomach, liver, urogenital system, placenta, thyroid cartilage, lungs, heart, and brain were depicted respectively. Some of these pictures (Fig. 2 and cover) were very beautiful, while others (Fig. 3) were clumsily drawn. Some of these pictures are very similar to drawings of Andreas Vesalius. According to Gillispie [4], some medical historians have claimed that Guidi may have plagiarized Andreas Vesalius and Gabriele Falloppio.

\section{Conclusion}

Gillispie [4] stated that Guidi was a traditional physician and remained in classical Galenism. Many of the pictures added to the book by his nephew which was published after his death were criticized in the following years. Nevertheless, Guidi has made a great effort to convey the knowledge of the previous scientists to next scientists and has contributed many contributions to anatomy with his own works. For these reasons, he should be appreciated.

\section{Compliance with ethical standards}

Conflict of interest None 


\section{References}

1. Vidus Vidius. https://en.wikipedia.org/wiki/Vidus_Vidius Accessed 10.07.2018

2. Tubbs RS, Salter EG (2006) Vidius Vidius (Guido Guidi) (C. 15091569). Neurosurgery 59:201-203. https://doi.org/10.1227/01.NEU. 0000219238.52858 .47

3. Thompson CJS (1925) The Scamnum, as described by Guido Guidi, illustrated by an Actual Specimen of the Sixteenth Century.
Proceedings of the Royal Society of Medicine 18(Sect_Hist_Med): $13-15$

4. Gillispie CC (ed) (1975) Dictionary of scientific biography. Vol. 5. New York, NY (USA)

5. Üstün Ç (2003) Guido Guidi's short biography and his eponyms (the vidian artery, nerve and canal). Journal of Inonu University Medical Faculty 10:51-53 